\title{
Effects of dietary vitamin E supplementation on fattening performance, carcass characteristics and meat quality traits of Karya male lambs
}

\author{
OKAN ATAY, ÖZDAL GÖKDAL, VADULLAH EREN, ŞEVKI ÇETINER and HAKAN YIKILMAZ
}

Adnan Menderes University, Cine Vocational School, Çine-Aydın, Turkey

\section{Abstract}

The objective of this study was to evaluate the effects of dietary vitamin E supplementation on performance, slaughter-carcass characteristics and meat quality traits of Karya male lambs. Lambs weaned approximately at 10 weeks of age were divided into two groups. After the 10 days adaptation period, control group (CG, $n=7)$ and vitamin E group (VEG, $n=6$ ) lambs were fed on with concentrates ad libitum and $100 \mathrm{~g}$ hay/lamb/day for 70 days. In addition the VEG received a supplement on concentrates of $45 \mathrm{mg} / \mathrm{lamb} /$ day vitamin $\mathrm{E}$ during the fattening period. The meat quality traits were determined using $\mathrm{m}$. longissimus dorsi (LD) obtained from split between 12th and 13th ribs on both groups lambs. Daily gain and feed conversion efficiency were $259 \mathrm{~g}$ and 5.3 for CG and $266 \mathrm{~g}$ and 4.7 for VEG, respectively. There was no vitamin $E$ supplementation effect on the average daily weight gain and feed conversion efficiency $(P>0.05)$. However, VEG had $10.5 \%$ higher feed conversion efficiency than control lambs. Slaughter and carcass characteristics of lambs were not significantly affected from vitamin $E$ supplementation $(P>0.05)$. There were no effects of vitamin $E$ supplementation on lightness $\left(L^{*}\right)$, redness $\left(a^{*}\right)$, yellowness $\left(b^{*}\right)$ and $\mathrm{pH}$ during 12-day aerobic storage. Thiobarbituric acid reactive substances (TBARS) values at day 2 were not affected by the vitamin $E$ treatment. However, TBARS values on day 4 and $8(P<0.05)$, and day $12(P<0.01)$ were higher in the $C G$ than in the VEG. Although not significant, $10 \%$ higher feed conversion efficiency in VEG animals might suggest that vitamin $E$ supplementation is useful to improve fattening performance.

Keywords: lamb, Karya, vitamin E, carcass, meat colour, TBARS, pH

\section{Zusammenfassung}

\section{Wirkung einer Vitamin E Futterergänzung auf Mastleistung, Schlachtkörper- eigenschaften und Fleischqualität bei männlichen Karya Lämmern}

Es sollte die Wirkung einer Vitamin E Futterergänzung auf Mast- und Schlachtergebnisse männlicher Lämmer der Rasse Karya untersucht werden. Nach dem Absetzen der Lämmer im Alter von 10 Wochen erfolgte die Bildung von zwei Gruppen. Beide Gruppen erhielten nach einer zehntägigen Anpassungszeit ad libitum Konzentratfutter und $100 \mathrm{~g}$ Heu über einen Zeitraum von 70 Tagen. Neben der Kontrollgruppe (CG, $n=7$ Tiere) erhielt die Versuchsgruppe (VEG, $n=6$ Tiere) $45 \mathrm{mg}$ Vitamin E je Tier und Tag. Die Fleischqualitätsmerkmale wurden am m. longissimus dorsi (LD) zwischen der 12. und 13. Rippe erfasst. Die tägliche Gewichtszunahme 
und Futterverwertung bei den Gruppen CG und VEG betrug $259 \mathrm{~g}$ und 5,3 bzw. $266 \mathrm{~g}$ und 4,7. Die Gewichtsunterschiede zwischen den Gruppen waren nicht signifikant. Die Futtereffizienz lag bei der VEG um 10,5\% besser als bei der CG. Bei den Schlachtkörpereigenschaften und Qualitätsmerkmalen konnten keine signifikanten Unterschiede nachgewiesen werden. Die TBARS Werte waren bei der VEG am 4., 8. und 12. Tag höher als bei der CG. Lediglich die um $10 \%$ bessere Futtereffizient rechtfertigt eine Vitamin E Futterergänzung.

Schlüsselwörter: Lamm, Karya, Vitamin E, Schlachtkörper, Fleischfarbe, TBARS, pH

\section{Introduction}

All tocopherols and tocotrienols are known as Vitamin E. Biologically most active and natural form of vitamin E is $\alpha$-tocopherol (AZZI and STOCKER 2000). Vitamin E is a necessary dietary supplement for growth, reproduction, immune function, disease prevention, enhancement and tissue integrity. Vitamin $E$ is a lipid soluble and chain breaking antioxidant that protects cellular membranes against oxidative damages. Since meat is processed by mechanical tools, the risk of oxidation via air and tools is high. Therefore colour, flavour and odour characteristics of meat can be affected during mechanical processing. During storage of meat and meat products, lipid oxidation is the main factor for loss of quality. Lipid oxidation causes negative changes on structure and nutritition value as well as colour, flavour and odour of meat (LAHUCKY et al. 2000, 2005). The colour stability of meat is important for retailers and consumers. Changes in meat colour are interpreted as effects of improper storage conditions. It is reported that supplementation of vitamin $E$ delays colour change, decreases drip loss and may provide lasting of meat shelf life (ASGHAR et al. 1991, LAHUCKY et al. 2005)

In recent years, many studies were conducted on effects of dietary vitamin $E$ supplementation on various animal performances (STROHECKER et al. 1997, DUFRASNE et al. 2000, MACIT et al. 2003a,b, LAUZURICA et al. 2005, KRSKA et al. 2001, KOLODZIEJ and JACYNO 2005), meat quality characteristics (meat colour, pH etc.), oxidative stability and shelf life of meat products in cattle (ROBBINS et al. 2003), on pork (LAHUCKY et al. 2005), on lamb (GUIDERA et al. 1997, MACIT et al. 2003a,b, LAUZURICA et al. 2005). The objective of this study was to evaluate the effects of dietary vitamin $E$ supplementation on fattening performance, slaughter-carcass characteristics and meat quality traits of Karya male lambs.

\section{Material and methods}

This study was carried out at the Research and Practice Farm of Çine Vocational High School, Adnan Menderes University, Aydın, Turkey. Karya (KARACA et al. 2004) male lambs $(n=13)$ weaned at 10 weeks of age were used in the study. The lambs were randomly divided into two groups, Vitamin E (VEG, $n=6)$ and Control ( $C G, n=7)$ lambs. After the 10 days adaptation period, the live weights of all lambs (three consecutive days after adaptation period) were recorded as initial weight. The animals were housed in groups according to treatment and were fed a concentrate mixture ad libitum and $100 \mathrm{~g}$ clover hay/lamb/day. During the 70 days fattening period, commercially available concentrate containing $90 \%$ dry matter and $167.7 \mathrm{~g}$ crude protein, $60,9 \mathrm{~g}$ crude ash and $24.4 \mathrm{~g}$ crude 
fat $/ \mathrm{kg}$ and $2407 \mathrm{ME}$, $\mathrm{kcal} / \mathrm{kg}$ was fed to lambs. The hay contained $91.2 \%$ dry matter and $139 \mathrm{~g}$ crude protein and $375 \mathrm{~g}$ crude fibre/ $\mathrm{kg}$. In addition, VEG received a supplement of $45 \mathrm{mg} / \mathrm{lamb} /$ day (MACIT et al. 2003a) vitamin E (DL- $\alpha$-tocopherol acetate) during the fattening period. Live weights of all lambs were recorded every second week. Final weights of all lambs were recorded at the end of the fattening period after $12 \mathrm{~h}$ fasting and then after $24 \mathrm{~h}$ fasting prior to slaughter. Concentrate consumption of the groups was recorded periodically. All animals were slaughtered at the end of the fattening period. After complete eviceration and dressing, warm carcass weights were taken. The head, skin, feet, genitalia and offal were weighed. Internal fat deposited around the kidneys (perinephric fat) and around the gastrointestinal tract (gut fat) was separated and weighed. Carcasses were chilled for $24 \mathrm{~h}$ at $4^{\circ} \mathrm{C}$ and cold carcasses were weighed. The tails were removed at its articulation and the cannon bones were dissected from the carcasses. The cold carcasses were split into symmetrical two parts along the backbone and leg depth, leg width, leg length, rump width, chest depth, chest width and shoulder width were measured on the whole and left half of the carcasses. The left half of the carcasses were cut into six parts according to the procedure given by COLOMER-ROCHER et al. (1987) and weighed. The surface area of a cross section of the $m$. longissimus dorsi (LD) between the 12th and 13th ribs was traced onto an acetate paper and measured using a planimeter. Dressing percentage was calculated as a ratio of $24 \mathrm{~h}$ fasting weight prior to slaughter and cold carcass weight. Proportional weights were calculated as the ratio of the heart, lungs and liver weights relative to slaughter weight. The proportional weights of the testes and internal fat were calculated relative to warm carcass weight and those of the other organs and carcass cuts relative to the cold carcass weight.

The $\mathrm{pH}$ values were measured in the whole carcass immediately after the slaughter and again after $24 \mathrm{~h}$. Meat quality traits were determined on steak cuts from LD on three lambs (according to mean live weights). The LD muscles were maintained under fluorescent light up to 12 days. The $\mathrm{pH}$ measured on freshly cut surfaces of LD muscle by direct probe of the pH meter (IQ 240, PH26-SS).

Meat colour was determined using a Minolta CR 300 (Minolta Camera Co., LTD, Osaka, Japan) using illuminant D65. Reflectance was determined over $400-700 \mathrm{~nm}$ range then $L^{*}, a^{*}$ and $b^{*}$ values were calculated. A steak was divided into five slices and individually placed in polystyrene trays covered by oxygen permeable polyethylene film and stored at $4 \pm 1^{\circ} \mathrm{C}$ for period 2, 4, 8 and 12 days (DUFRASNE et al. 2000, MACIT et al. 2003 a) after the slaughter. And then it was assessed for colour and oxidative rancidity by the thiobarbutiric acid reactive substances (TBARS) procedure. The TBARS concentrations were measured according to the procedure given by TARLADGIS et al. (1960) and expressed as $\mathrm{mg}$ malonaldehyde equivalents per $\mathrm{kg}$ of fresh meat.

The mathematical model for the analysis of growth performance, live weight, carcass characteristics and meat quality traits included fixed effects due to group and random effect due to residual error (SAS 1998). The Student's t-test was used to detect significant differences between means. Daily feed consumption and feed conversion efficiency were calculated on a group basis. 


\section{Results and discussion}

Initial and final weight of CG and VEG lambs were $12.73 \mathrm{~kg}$ and $13.22 \mathrm{~kg}$, and $31.37 \mathrm{~kg}$ and $31.38 \mathrm{~kg}$, respectively. There were no significant effect of groups on the initial and final weight of lambs $(P>0.05)$. The differences between the daily weight gains ( $266 \mathrm{~g}$ vs. $259 \mathrm{~g}$ ) and feed conservation efficiency (4.7 vs. 5.3) for 70 days were found not be significant $(P>0.05)$ (Table 1). However, animals in VEG had $10.5 \%$ higher feed conversion efficiency and $2.56 \%$ higher daily weight gain than those in CG. Similar results have been reported by MACIT et al. $(2003 a, b)$ on Morkaraman male lambs. The present results were also in agreement with the results of STROHECKER et al. (1997) and LAUZURICA et al. (2005).

Table 1

Means ( \pm standard error) live weights, weight gain and feed conversion efficiency in CG and VEG lambs Lebendgewicht, tägliche Gewichtszunahme und Futtereffizienz der Gruppen CG und VEG

\begin{tabular}{|c|c|c|}
\hline \multirow{2}{*}{ Traits } & \multicolumn{2}{|c|}{ Groups } \\
\hline & CG $(n=7)$ & $\operatorname{VEG}(n=6)$ \\
\hline Initial weight, kg & $13.218 \pm 0.97$ & $12.730 \pm 0.82$ \\
\hline Final weight, kg & $31.381 \pm 2.20$ & $31.371 \pm 1.27$ \\
\hline Daily weight gain, g & $259 \pm 10.7$ & $266 \pm 11.5$ \\
\hline Feed conversion efficiency & 5.3 & 4.7 \\
\hline
\end{tabular}

Carcass measurements, slaughter and carcass characteristics of the two groups of lambs are presented in Table 2 . The leg depth, rump width, leg width and leg length of the VEG lambs tended to be higher than the CG lambs, $(P>0.05)$. In the present study dietary vitamin $E$ supplementation did not have any significant effect $(P>0.05)$ on the slaughter and carcass characteristics of lambs. All examined traits were similar for both groups (Table 2). Similar results have been reported by MACIT et al. $(2003 a, b)$.

The changes in $L^{*}, a^{*}$ and $b^{*}$ values over the 12 day storage period after slaughter are presented in Table 3. No significant differences were found on colour parameters $(P>0.05)$. Changes in $a^{*}$ values on LD for the CG and VEG are given in Figure 1.

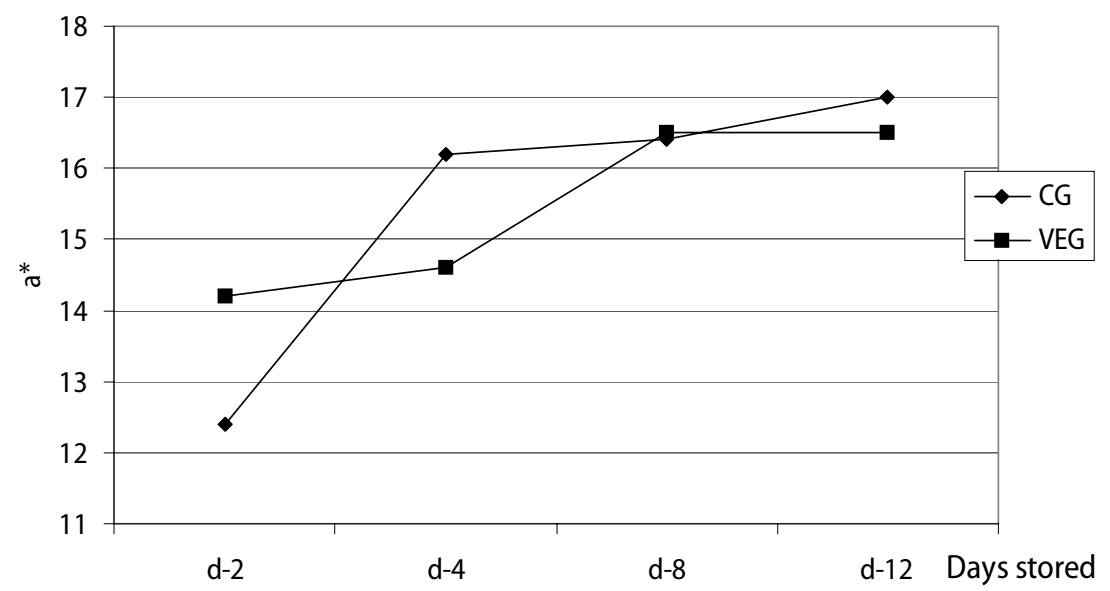

Figure1

Changes in redness ( $\mathrm{a}^{*}$ ) in $\mathrm{m}$. longissimus dorsi during storage for the CG and VEG

Veränderung der Fleischfarbe vom 2. bis 12. Tag im Vergleich der Gruppen CG und VEG 
Table 2

Means ( \pm standard error) slaughter and carcass characteristics in CG and VEG lambs

Schlachtmerkmale der Gruppen CG und VEG

\begin{tabular}{|c|c|c|}
\hline \multirow{2}{*}{ Traits } & \multicolumn{2}{|c|}{ Groups } \\
\hline & CG $(n=7)$ & $\mathrm{VEG}(n=6)$ \\
\hline \multicolumn{3}{|l|}{ Carcass measurements, $\mathrm{cm}$} \\
\hline Chest depth & $25.557 \pm 0.524$ & $24.833 \pm 0.380$ \\
\hline Leg depth & $9.044 \pm 0.349$ & $9.848 \pm 0.368$ \\
\hline Shoulder width & $16.471 \pm 0.613$ & $16.200 \pm 0.502$ \\
\hline Rump width & $16.800 \pm 0.816$ & $17.016 \pm 0.896$ \\
\hline Leg width & $6.518 \pm 0.400$ & $6.926 \pm 0.369$ \\
\hline Leg length & $28.214 \pm 0.730$ & $28.416 \pm 0.523$ \\
\hline MLD area, $\mathrm{cm}^{2}$ & $11.357 \pm 0.752$ & $10.183 \pm 0.57$ \\
\hline Fat thickness over LD, mm & $2.11 \pm 0.238$ & $1.69 \pm 0.205$ \\
\hline \multicolumn{3}{|c|}{ Carcass weight, kg and dressing percentage, $\%$} \\
\hline Slaughter weight & $31.771 \pm 2.423$ & $30.808 \pm 1.501$ \\
\hline Warm carcass weight & $15.922 \pm 1.183$ & $15.630 \pm 0.722$ \\
\hline Cold carcass weight & $15.524 \pm 1.137$ & $15.160 \pm 0.697$ \\
\hline Dressing percentage & $48.94 \pm 0.51$ & $49.50 \pm 1.91$ \\
\hline \multicolumn{3}{|l|}{ Offal items, kg } \\
\hline Head weight & $1.937 \pm 0.125$ & $1.913 \pm 0.059$ \\
\hline Internal fat weight & $0.224 \pm 0.035$ & $0.245 \pm 0.017$ \\
\hline 4 feet weight & $0.797 \pm 0.052$ & $0.825 \pm 0.039$ \\
\hline Skin weight & $3.252 \pm 0.279$ & $3.470 \pm 0.270$ \\
\hline Heart, lungs and liver weight & $1.357 \pm 0.100$ & $1.265 \pm 0.078$ \\
\hline Testes weight & $0.175 \pm 0.034$ & $0.163 \pm 0.027$ \\
\hline Kidney weight & $0.097 \pm 0.006$ & $0.103 \pm 0.008$ \\
\hline Spleen weight & $0.072 \pm 0.007$ & $0.051 \pm 0.003$ \\
\hline Kidney and pelvic fat weight & $0.249 \pm 0.031$ & $0.228 \pm 0.017$ \\
\hline Tail weight & $0.315 \pm 0.031$ & $0.431 \pm 0.090$ \\
\hline \multicolumn{3}{|c|}{ Wholesale cuts of left half of carcass, kg } \\
\hline Leg weight & $2.407 \pm 0.169$ & $2.378 \pm 0.120$ \\
\hline Back-loin weight & $1.580 \pm 0.143$ & $1.452 \pm 0.104$ \\
\hline Forearm weight & $1.384 \pm 0.095$ & $1.358 \pm 0.053$ \\
\hline Shoulder weight & $0.628 \pm 0.056$ & $0.516 \pm 0.047$ \\
\hline Neck weight & $0.697 \pm 0.070$ & $0.708 \pm 0.120$ \\
\hline Flank-chest weight & $0.675 \pm 0.077$ & $0.685 \pm 0.056$ \\
\hline \multicolumn{3}{|c|}{ Proportional yields (percentage \pm standard error) of wholesale carcass cuts and organs to cold carcass weights } \\
\hline Heart, lungs and liver & $4.287 \pm 0.096$ & $4.101 \pm 0.126$ \\
\hline Testes & $1.074 \pm 0.197$ & $1.025 \pm 0.151$ \\
\hline Kidney & $0.628 \pm 0.056$ & $0.684 \pm 0.052$ \\
\hline Kidney and pelvic fat & $1.577 \pm 0.099$ & $1.514 \pm 0.109$ \\
\hline Internal fat & $1.370 \pm 0.159$ & $1.566 \pm 0.083$ \\
\hline Tail & $2.034 \pm 0151$ & $2.803 \pm 0.497$ \\
\hline Legs* & $15.528 \pm 0.623$ & $15.683 \pm 0.329$ \\
\hline Back-loin* & $20.400 \pm 0.355$ & $19.89 \pm 0.557$ \\
\hline Shoulder* & $4.056 \pm 0.239$ & $3.392 \pm 0.224$ \\
\hline Flank-Chest* & $4.295 \pm 0.266$ & $4.530 \pm 0.331$ \\
\hline Fore-arm* & $8.950 \pm 0.147$ & $8.978 \pm 0.147$ \\
\hline Neck* $^{*}$ & $4.518 \pm 0.324$ & $4.691 \pm 0.238$ \\
\hline
\end{tabular}

* relative to cold half carcass weights 
Table 3

Mean ( \pm standard error) colour parameters of $m$. longissimus dorsi during storage for the CG and VEG Fleischfarbmerkmale am M. longissimus dorsi am 2. bis 12. Tag nach der Schlachtung

\begin{tabular}{lccccccc}
\hline & \multirow{2}{*}{$N$} & \multicolumn{2}{c}{$\mathrm{L}^{*}$} & \multicolumn{2}{c}{$\mathrm{a}^{*}$} & \multicolumn{2}{c}{$\mathrm{b}^{*}$} \\
& & CG & VEG & CG & VEG & CG & VEG \\
\hline Day 2 & 3 & $42.0 \pm 1.60$ & $43.5 \pm 1.34$ & $12.4 \pm 2.15$ & $14.2 \pm 1.73$ & $10.8 \pm 1.04$ & $10.1 \pm 0.10$ \\
Day 4 & 3 & $47.0 \pm 1.52$ & $48.3 \pm 1.01$ & $16.2 \pm 0.99$ & $14.6 \pm 0.88$ & $12.9 \pm 0.69$ & $12.3 \pm 0.88$ \\
Day 8 & 3 & $47.7 \pm 1.35$ & $47.7 \pm 1.28$ & $16.4 \pm 1.23$ & $16.5 \pm 1.48$ & $14.8 \pm 0.65$ & $14.6 \pm 1.31$ \\
Day 12 & 3 & $46.0 \pm 1.44$ & $47.0 \pm 1.14$ & $17.0 \pm 0.69$ & $16.5 \pm 1.44$ & $14.5 \pm 0.52$ & $15.7 \pm 1.12$ \\
\hline
\end{tabular}

Colour stability can be affected by many factors such as muscle type, diet, storage period, storage temperature and oxygen availability.

Many studies were conducted on the effects of vitamin E on meat colour although those studies were differed in terms of storage period, packaging, and amount of vitamin E supplementation (KRSKA et al. 2001).

These results are in agreement with those of MACIT et al. (2003 b) who found no differences in $L^{*}, a^{*}$ and $b^{*}$ values on $L D$ during 12 day storage period between vitamin $E$ supplemented ( $45 \mathrm{mg} / \mathrm{lamb} /$ day for the 75 day before slaughter) and control Awassi lambs.

However, GUIDERA et al. (1997) reported that colour stability of a-tochopherol supplemented $(1000 \mathrm{mg} / \mathrm{kg}$ ) group lambs had more favourable than control group lambs. Researchers also reported that vitamin E supplementation delayed metmyoglobin formation on lamb patties under modified atmosphere condition (KERRY et al. 2000), and increased oximyoglobin formation of lamb meat stored under modified atmosphere during 14 days, in Manchego breed (LAUZURICA et al. 2005).

TBARS values during storage are given in Table 4 and Figure 2. TBARS values of fresh meat were low in both groups at day 2 and did not differ significantly. However, TBARS values increased after day 2 and differed significantly on days $4,8(P<0.05)$ and 12 $(P<0.01)$ between $C G$ and VEG animals.

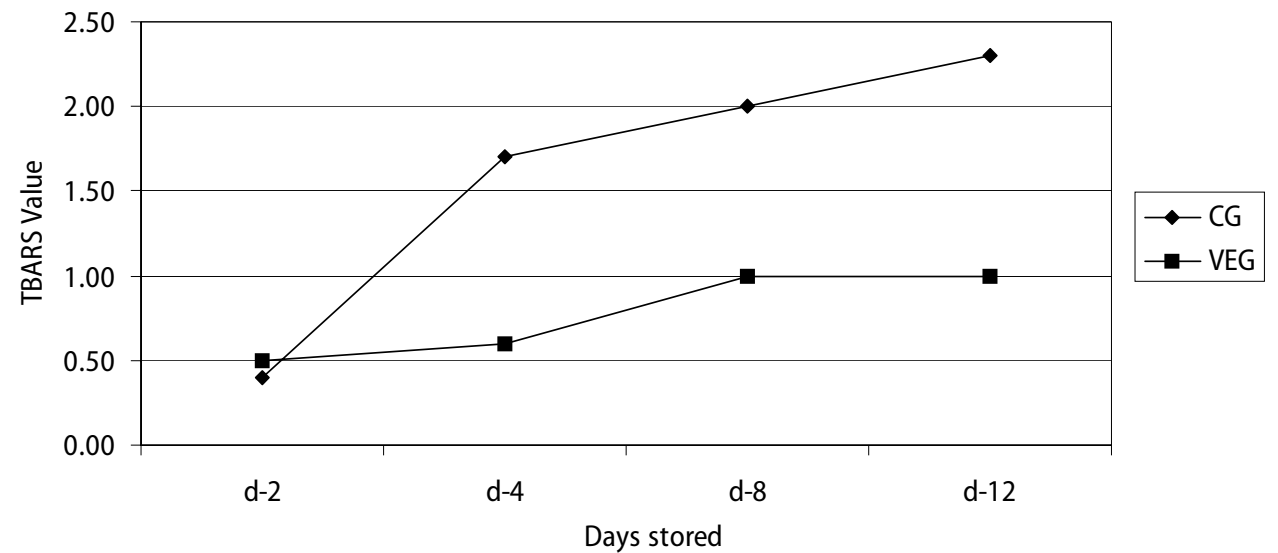

Figure 2

Changes in TBARS values in $m$. longissimus dorsi during storage for CG and VEG

Veränderung der Fleischfarbe vom 2. bis 12. Tag im Vergleich der Gruppen CG und VEG 
Table 4

Mean ( \pm standard error) TBARS values of $m$. longissimus dorsi during storage for CG and VEG

TBARS-Werte des M. longissimus dorsi vom 2. bis 12. Tag nach der Schlachtung

\begin{tabular}{llccc}
\hline Days & $N$ & \multicolumn{2}{c}{ TBARS, mg malanoaldehyde/kg fresh meat } \\
\hline Day 2 & CG & $0.4 \pm 0.06$ & $0.5 \pm 0.17$ & $P$ \\
Day 4 & 3 & $1.7 \pm 0.35$ & $0.6 \pm 0.09$ & VEG \\
Day 8 & 3 & $2.0 \pm 0.35$ & $1.0 \pm 0.14$ & $*$ \\
Day12 & 3 & $2.3 \pm 0.15$ & $1.0 \pm 0.57$ & $* *$ \\
\hline
\end{tabular}

ns not significant $(P>0.05),{ }^{*}$ within rows differences were significant at $P<0.05,{ }^{* *}$ within rows differences were significant at $P<0.01$

These findings are consistent with those of STROHECKER et al. (1997) who found a delay in lipid oxidation during storage in lamb meat supplemented with $2000 \mathrm{IU}$ a-tocopheryl acetate.

Similarly, LOPEZ-BOTE et al. (2001) reported the TBARS value of meat from under refrigerated and dark conditions during 9 days as $0.45 \mathrm{mg} \mathrm{MDA} / \mathrm{kg}$ muscle for lambs supplemented with $1000 \mathrm{mg}$ of vitamin $\mathrm{E} / \mathrm{kg}$, whereas the TBARS value for nonsupplemented lambs was $3.1 \mathrm{mg} \mathrm{MDA} / \mathrm{kg}$ muscle.

MACIT et al. (2003a) found that TBARS values on LD of Morkaraman male lambs fed vitamin $E$ supplemented diet were lower $(P<0.05)$ at days 2 , day 4 , day 8 and day 12 , than those of controls.

Similarly, protective effect of dietary vitamin $E$ supplementation against lipid oxidation under various conditions in lamb (KERRY et al. 2000, MACIT et al. 2003b, LAUZURICA et al. 2005) and pork (BUCKLEY et al. 1989, ASGHAR et al. 1991, LAHUCKY et al. 2005) was reported. The results presented here are in consistent with those mentioned above.

In this study, $\mathrm{pH}$ values of whole carcass at slaughter and $24 \mathrm{~h}$ after slaughter were not different between groups. Similarly, pH values of LD muscles on days 2, 4, 8 and 12 (Table 5) were not different between groups.

Table 5

Mean ( \pm standard error) $\mathrm{pH}$ values in whole carcass at slaughter and after $24 \mathrm{~h}$ and $m$. longissimus dorsi during storage for CG and VEG

pH Werte im m. longissimus dorsi und dem Gesamtschlachtkörper bei den Gruppen CG und VEG

\begin{tabular}{|c|c|c|c|c|}
\hline \multirow{2}{*}{ Days } & \multirow{2}{*}{$N$} & \multicolumn{3}{|c|}{$\mathrm{pH}$} \\
\hline & & CG & VEG & $P$ \\
\hline Day 2 & 3 & $5.7 \pm 0.08$ & $5.5 \pm 0.05$ & ns \\
\hline Day 4 & 3 & $6.0 \pm 0.26$ & $5.8 \pm 0.17$ & ns \\
\hline Day 8 & 3 & $5.9 \pm 0.19$ & $5.5 \pm 0.06$ & ns \\
\hline Day 12 & 3 & $5.2 \pm 0.18$ & $5.7 \pm 0.06$ & ns \\
\hline \multicolumn{5}{|c|}{ In whole carcass } \\
\hline At slaughter & 3 & $6.21 \pm 0.25$ & $6.24 \pm 0.27$ & ns \\
\hline $24 \mathrm{hr}$ & 3 & $5.50 \pm 0.07$ & $5.61 \pm 0.04$ & ns \\
\hline
\end{tabular}

ns not significant

LAUZURICA et al. (2005) found that dietary vitamin E supplementation had no effect on $\mathrm{pH} 24 \mathrm{~h}$ after salughter. Similar results have been reported by MACIT et al. (2003b) at different storage periods. 
In conclusion, dietary $45 \mathrm{mg} / \mathrm{lamb} /$ day vitamin E supplementation during 70 days resulted more favourably TBARS values of meat than those of nonsupplemented group lambs. Although not significant, 10\% higher feed conversion efficiency in VEG animals might suggest that vitamin $E$ supplementation is useful to improve fattening performance. Meat colour, $\mathrm{pH}$, slaughter and carcass characteristics were not influenced by vitamin $\mathrm{E}$ supplementation. In the vitamin E supplementation studies it has been reported that, lipid oxidation of meat, especially during the long storage periods was reduced by vitamin $\mathrm{E}$. However, the results obtained in studies related to the effects of vitamin $\mathrm{E}$ supplementation on meat colour and $\mathrm{pH}$ values were contradictory. In general, in studies related to the effects of vitamin E supplementation on performance, slaughter and carcass characteristics were found that performance was not affected by vitamin $E$ supplementation.

Nevertheless, since the number of animals used in the studyis relatively low, the absence of significant differences between groups should be further evaluated using more animals, different vitamin $\mathrm{E}$ doses and different storing and evaluating conditions of meat.

\section{Acknowledgements}

This research was supported by Adnan Menderes University Scientific Research Project Comission (ADU- BAP), Project No: ÇMYO: 04001.

\section{References}

Asghar A, Gray Jl, Booren AM, Gomaa EA Abouzied MM and Miller ER (1991) Influence of supranutritional dietary vitamin E levels on subcellular deposition of alpha-toco-pherol in the muscle and on pork quality. J Sci Food Agricult 57, 131-41

Azzi A and Stocker A (2000) Vitamin E Non-antioksidant roles. Progr Lipid Res 39, 231-55

Buckley DJ, Gray Jl, Asghar A, Price JF, Crackel RL, Booren AM, Pearson AM and Miller ER (1989) Effects of dietary antioxidants and oxidized oil on membranal lipid stability and pork product quality. J Food Sci 54, 1193-7

Colomer-Rocher F, Morand-Fehr P and Kirton AH (1987) Standard methods and procedures for goat carcass evaluation jointing and tissue separation. Livest Prod Sci 17, 149-57

Dufrasne I, Marche A, Clinquart JL, Hornick C, van Eenaeme C and Istasse L (2000) Effects of dietary vitamin $E$ supplementation on performance and meat characteristics in fattening bulls from the Belgian Blue Breed. Livest Prod Sci 65, 197-201

Guidera J, Kerry J P, Buckley D J, Lynch P B and Morrissey P A (1997) The effect of dietary vitamin E supplementation on the quality of fresh and frozen lamb meat. Meat Sci 45, 33-43

Karaca O, Cemal I, Aygün T, Altin T and Yildiz S (2004) Litter Size and Serum LH Levels in Prolific Kıvırcık and Karya Type Sheep. Yüzüncü Yıl Üniversitesi Ziraat Fakültesi Tarım Bilimleri Dergisi (J Agric Sci) $14,17-21 \mathrm{~m}$ [in Turkish]

Kerry JP, O'Sullivan MG, Buckley DJ, Lynch PB and Morrissey PA (2000) The effects of dietary a-tocopheryl acetate supplementation and modied atmosphere packaging (MAP) on the quality of lamb patties. Meat Sci 56, 61-6

Kolodziej A and Jacyno E (2005) Effect of selenium and vitamin E supplementation on reproductive performance of young boars. Arch Tierz 48, 68-75

Krska P, Lahucky R, Küchenmeister U, Nürnberg K, Palanska O, Bahelka I, Kuhn G and Ender K (2001) Effects of dietary organic selenium and vitamin $E$ supplementation on post mortem oxidative deterioration in muscles of pigs. Arch Tierz 44, 193-201

Lahucky R, Krska P, Küchenmeister U, Nürnberg K, Liptaj T, Nürnberg G, Bahelka I, Demo P, Kuhn G and Ender K (2000) Effect of vitamin E on changes in phosphorus compounds assessed by 31P NMR spectroscopy and ATPhase from post-mortem muscle samples and meat quality of pigs. Arch Tierz $43,487-97$ 
Lahucky R, Küchenmeister U, Bahelka I, Novotna K, Vasickova K and Ender K (2005) Effects of vitamin E by dietary supplementation and of calcium ascorbate by post mortem injection muscle on the antioxidative status and on meat quality of pigs. Arch Tierz 48, 592-600

Lauzurica S, de la Fuente J, Diaz M T, Alvarez I, Perez C and Caneque V (2005) Effect of Dietery Supplementation of Vitamin $\mathrm{E}$ on charecteristics of lamb meat packed under modified atmosphere. Meat Sci 70, 639-46

Lopez-Bote CJ, Daza A, Soares M and Berges E (2001) Doseresponse effect of dietary vitamin E concentration on meat quality characteristics in light-weight lambs. Anim Sci 73, 451-7

Macit M, Aksakal V, Emsen E, Aksu Mi, Karaoglu M and Esenbuga N (2003a) Effects of Vitamin E supplementation on performance and meat qulity traits of Morkaraman male lambs. Meat Sci 63, 51-5

Macit M, Aksakal V, Emsen E, Esenbuga N and Aksu Mi (2003b) Effects of vitamin E supplementation on fattening performance non-carcass components and retail cut percentages and meat qulity traits of Awassi lambs. Meat Sci 64, 1-6

Robbins K, Jensen J, Ryan KJ, Homco-Ryan C, McKeith FK and Brewer MS (2003) Dietary vitamin E supplementation effects on the color and sensory characteristics of enhanced beef steaks. Meat Sci 64, 279-85

SAS (1998) PC SAS user's Guide Statistics SAS Inst Carry. North Carolina USA

Strohecker MG, Faustman C, Furr H, Hoagland TA and Williams SN (1997) Vitamin E supplementation effects on color and lipid stability of whole and ground lamb. J Muscle Foods 8, 413-26

Tarladgis BG, Watts BM, Younathan MT and Dugan LR (1960) A Distilation Method for the quantitative determination of malonaldehyide in foods. J Am Oil Chem Soc 37, 44-8

Received 3 October 2007, accepted 22 July 2009.

Corresponding author:

A. Assoc. Prof. OKAN ATAY

email: oatay@adu.edu.tr

Adnan Menderes University, Çine Vocational School, 09500, Çine-Aydin, Turkey 